\title{
التفسـاد
}

\section{دراسة موضوعية في السنة النبوية}

\author{
اعلداد \\ محسن بن سعد بن عثماز الدوسري \\ باحث بقسم الكتاب والسنة \\ كلية الشريعة وأصول الدين - جامعة الملك خالد
}




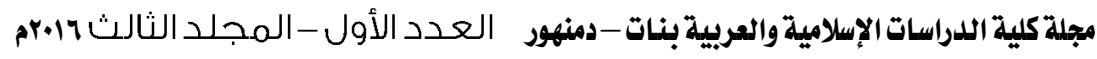

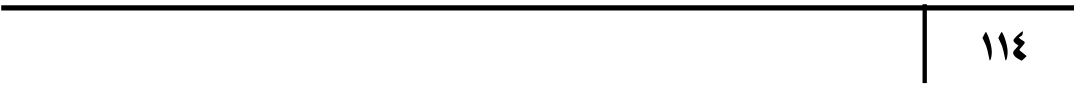




\section{المقدمة}

إن الحمد لله، نحمده ونسنعينه ونستغفره ونعوذ باله من شرور

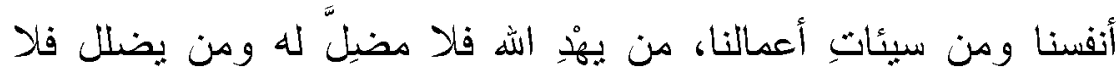

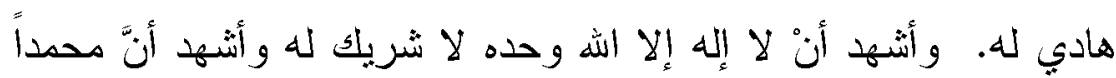

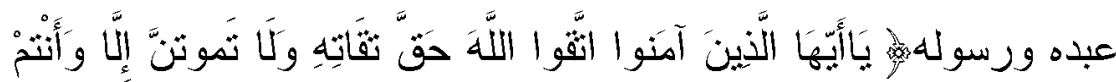

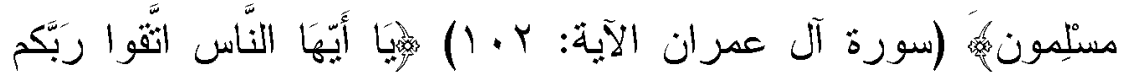

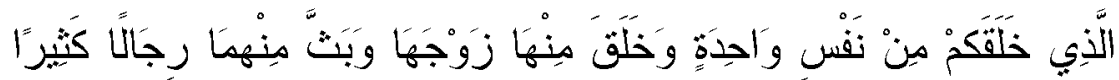

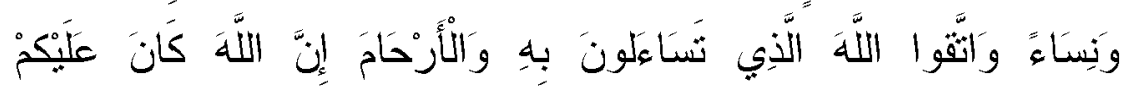

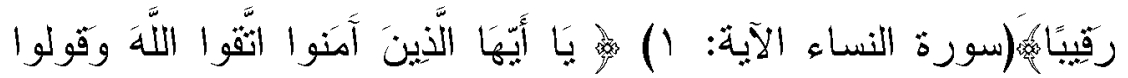

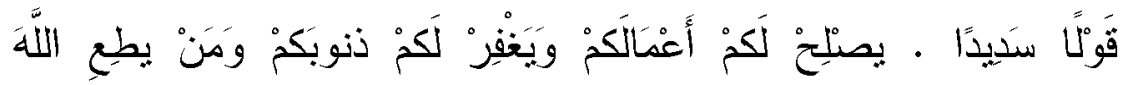

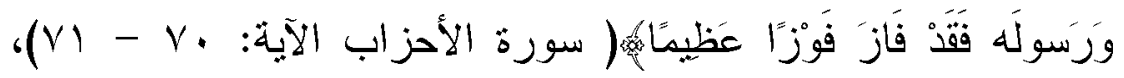
ونصلي ونسلم علي سيدنا وحيينا محمد، رسول الله وخيرثه من خلقه، خاتم النبيين وأشرث المرسلين، و وعلى آله وأصدابه ومن تبعهم بإحسان الى يوم الدين. وبعد ب...........

فهذا البحث بتحدث عن الفساد والذي ثتضح خطورثه على الفرد و الجماعة حيث بيتوعد اله صاحبه بأشد العقوبه وقد قمث بجمع ما تيسر من الأحاديث و اخترث ما كان صحيحًا أو حسنًا. ويهـف البحث إلمى ما بلية: - بيان منهج السنة النبوية في اجنثاث الفساد. -

- إيجاد نموذجاً نطبيقياً للحديث الموضوعي يعالج قضايا العصر ؛ مما يرسخ القناعة بأن السنة حاضرة في علاج

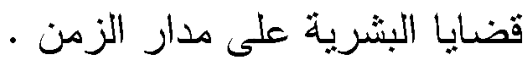


واثتنمل البحث على مقدمة وعدة مباحث وخاتمة وهي كما بليـ

- المبحث الأول: مفهوم الفساد ومدلو لاته في اللغة. - المبحث الثاني: صور الفساد و أنو اعه.

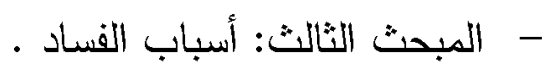
- المبحث الرابع: آثار الفساد. - المبحث الخامس: ثصدي الثر ع لمعالجة الفساد. - المبحث السادس: عقوبة الفساد. - المبحث السابع: علاج الفساد. الخاتمة وبها أهم النتائج. 


\section{المبحث الأول \\ مفهوم الفساد ومدلولاته في اللُّة}

الفنساد في اللفة:

قال ابن منظور في "لسان العرب": القسادُ: نقيض الصلاحة، فَسَدَ

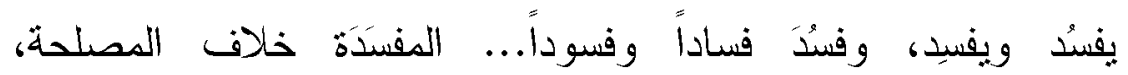

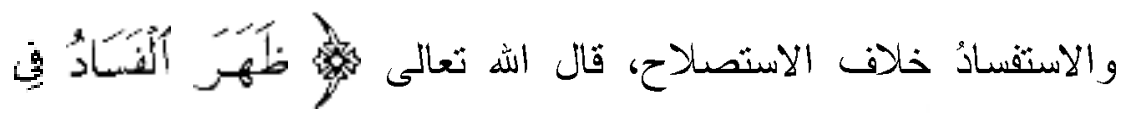

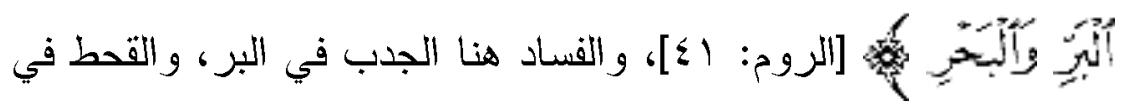
البحر • بعني المدن الني على ضفاف الأنهار ('). وقال ابن سبدة في "المحكم"، و الر اغب الأصفهاني في "المفرداث": "الفساد خروج الشيء عن الاعتدال، قليلخً كان الخروج أو كثيراً ويضاده الصلاح ويستعمل ذلك في النفس و البدن"(r). وقال الفيروز آبادي في "القاموس المحيط": "فَسَدَ كعَسَرَ، و القسساد: أخذ المال ظلماً، و المفسدة ضد المصلحة، وتفاسد القوم يعني ثقاطعوا

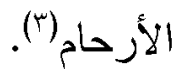

مما سقته من قول أئُة اللغة بتبين أن الفساد جاء في اللغة مقابلاً

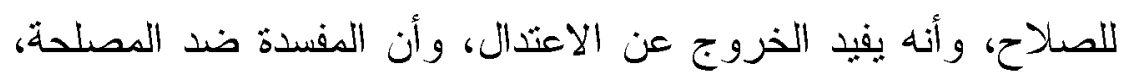

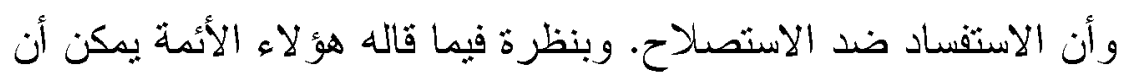
أخلص إلى أن الأشباء لها وظائفها التي تثوديها بتسخير وقدرة من الهذ الهاء

(1) (1) لسان العرب لابن منظور جr ص بrrr.

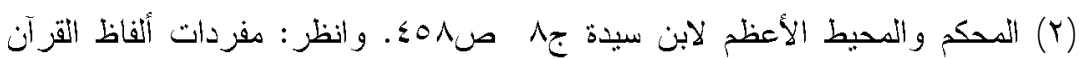

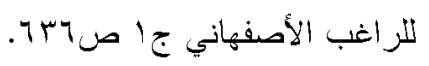

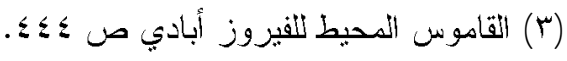


تعالى الذي أعدها لتقوم بأدوار مثوقعة منها ، وهذا هو صلاحها، وعند

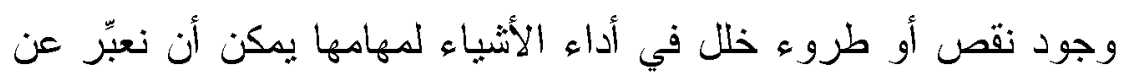
ذلك الخلل أو النقص بالفساد. وهذا الخلل وذاك النقص ناتج عن خروج الثيء نفسه عن وصفه المتعارف عليه، فهو خلل أو خروج عن الاعندال والاسثقامة من داخله،

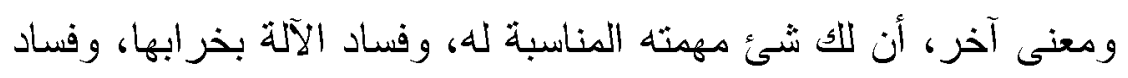

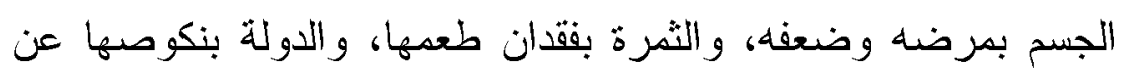

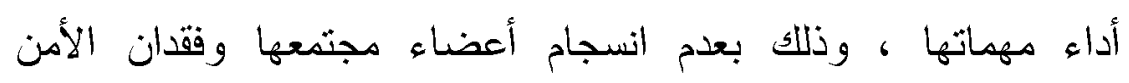
و الوحدة الذين بحفظان ثماسكها. و الفساد أمر مرفوض ومستهجن عند الوجدان السليم والفطرة المستقيمة، فإن الإنسان بفطرته السليمة التي فطره الله عليها يكره القساد ويميل إلى الصلاح، و الفساد مرفوض عند أهل العقل فالنفس لا تميل إلى الفساد ولا نسعى له، كما هو ملاحظ في كثير من القضابا التي

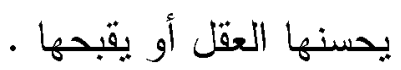

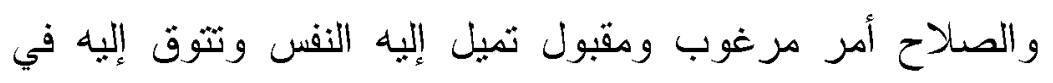
فطرثها السليمة هذا عن مدلول الفساد في اللغة، فما هو مفهوم الفساد في الاصطلخج 
قال الراغب: الفساد خروج الثنيء عن الاعتدال قليلا كان الخروج عليه أو كثيرا، ويستعمل في النفس والبدن والأشياء الخارجة النية

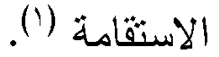

وقال المناوي: الفساد: هو انتقاض صورة الثشيء(r)، وفساد (البيوع) عند الققهاء ما كان مشروعا بأصله غير مشروع بوصفه، وهو يرادف البطلان عند الثافعية، وضده الصحة، ويشكل قسما قائما برأسه عند الأحناف: فالثيء عندهم إما صحيح، و إما باطل، و إما فاسد (بّا. وقال ابن الجوزي: والفساد: ثغير الثيء عما كان عليه من فئ الصـلاح، وقد يقال في الثنيء مع قيام ذاته، ويقال فيه مع انتقاضها، ويقال فيه إذا بطل وزال، ويذكر الفساد في الدين كما بذكر في الذات، فتارة يكون بالعصيان، وتارة بالكفر، ويقال في الأقوال إنها فاسدة إذا ولها

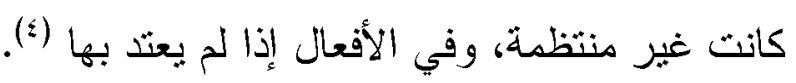
مدلول مصطلح الفساد في السنة المطهرة:

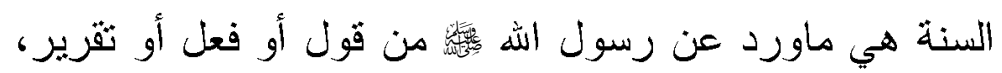
وهي الأصل الثاني من أصول الدين، وهي رفيقة القرآن الكريم وصنوه .

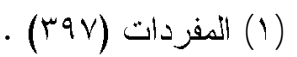

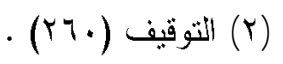

المرجع السابق نفسه، و الصفحة نفسها، وقد نقل المناوي و الجرجاني تعزيف

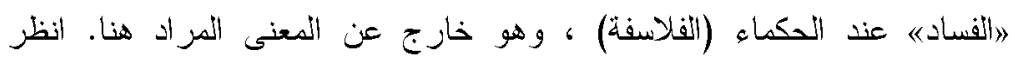

$$
\begin{aligned}
& \text { التعريفات للجزجاني (IVT) } \\
& \text { نزهة الأعين النواظر (. ن. }
\end{aligned}
$$


وتأتي أحاديث الرسول :

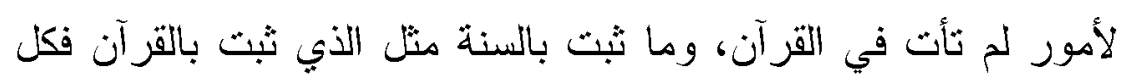
من عند الهه.

ونحن إذا استعرضنا الأحاديث الني جاء فيها مصطلح الفساد

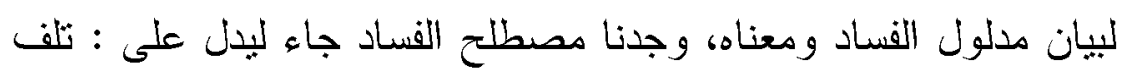
الثيء وذهاب نفعه .

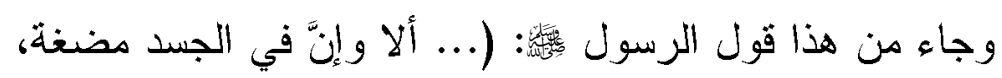

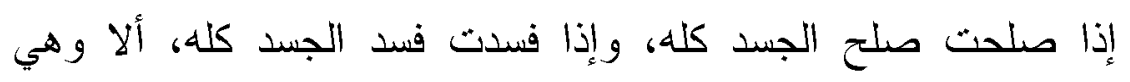

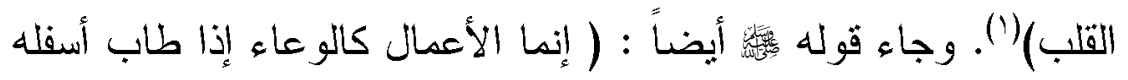
طاب أعلاه، وإذا فسد أسفله فسد أعلاد) (r).

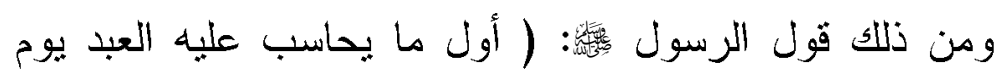

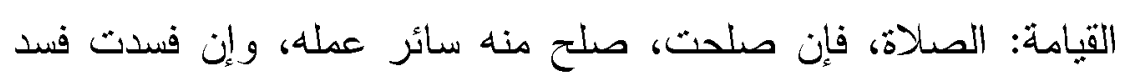
سائر عمله) (ب).

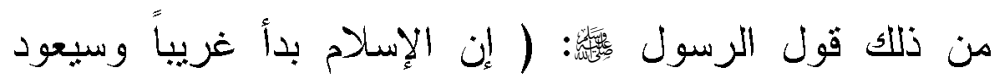

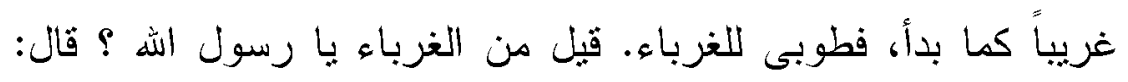

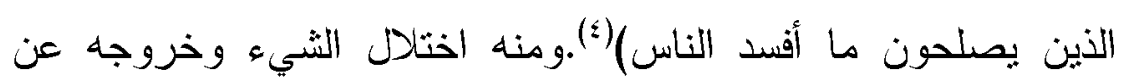

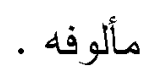

(1) أخرجه الشيخان: البخاري في كتاب الإيمان برقم .0، ومسلم في كتاب المساقاة برقم .1997

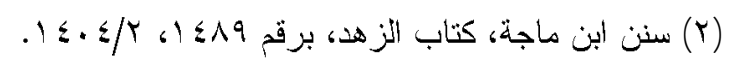

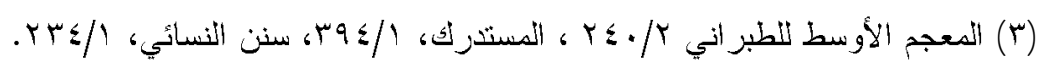

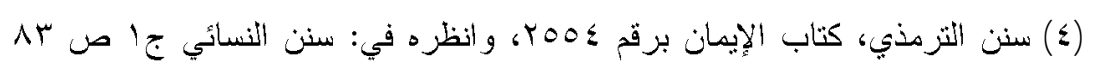

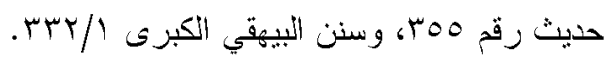


وفي هذا المعنى جاء حديث عائشة ـ رضي اله عنها ـ قالت:

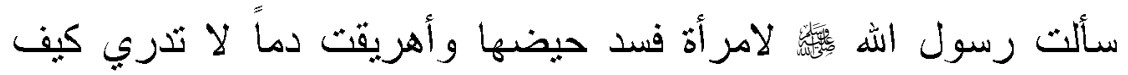

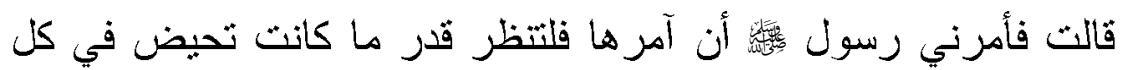

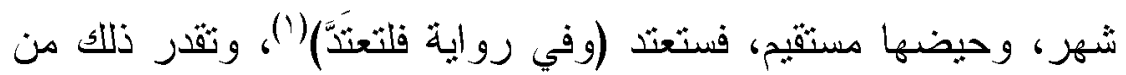

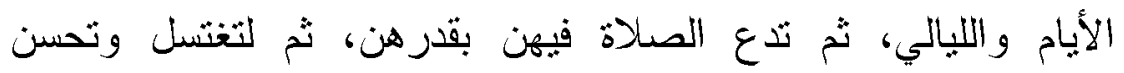

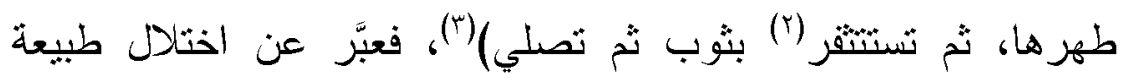

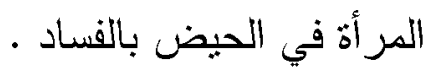

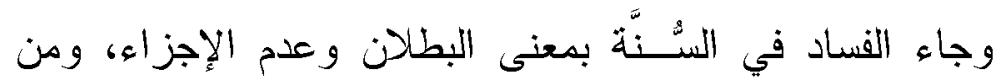

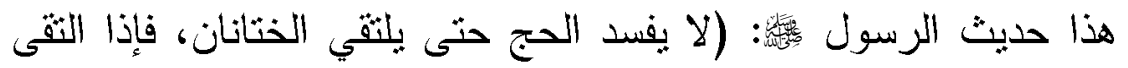
الختانان فسد الحج ووجب الغرم)(汭 ومعنى فساد الحج هنا بطلانه شرعاً.

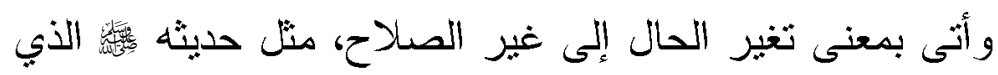

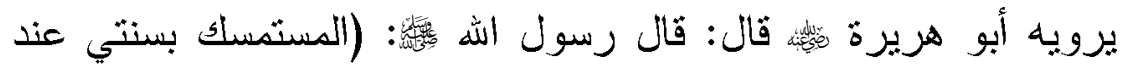

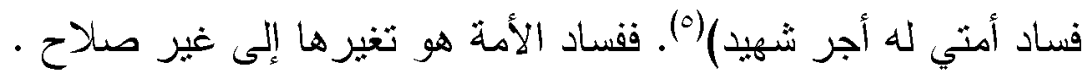

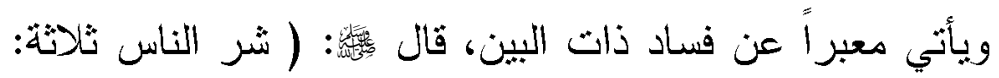
متكبر على والديه، بحقرهما، ورجل سعى في فساد بين الناس بالكذب حتى يثباغضو ا ويثباعدوا)(").

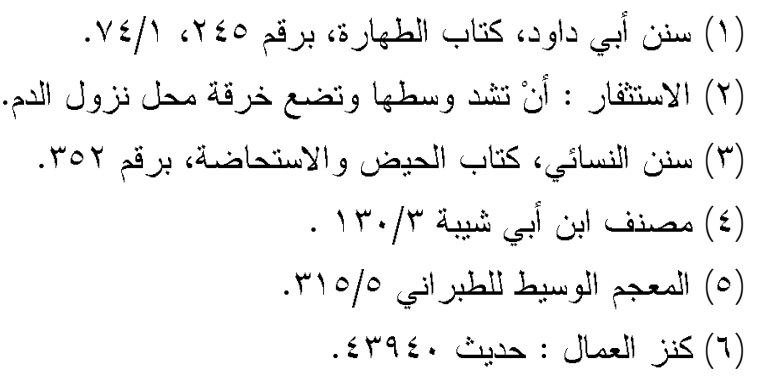




\section{المبحث الثاني \\ صور الفساد وأنواعه}

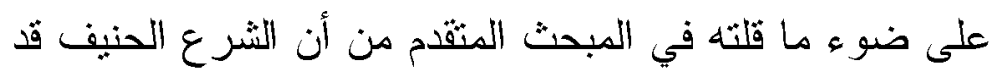
جعل كل المعاصي فساداً في الأرض فإن الفساد قد يكون في العقيدة فيكون فساداً عقدياً وهو أسوأ أنواع الفساد وصوره، وقد يكون أمنياً

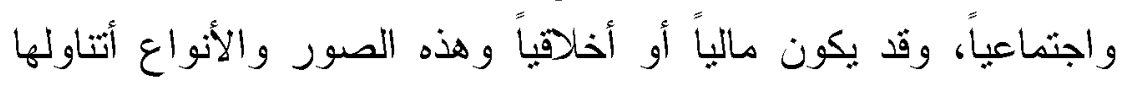
بالثرح في هذا المبحث. . الفساد العقدي : البري

وهو فساد الاعثقاد الذي هو أساس كل فساد ، فسعي الإنسان

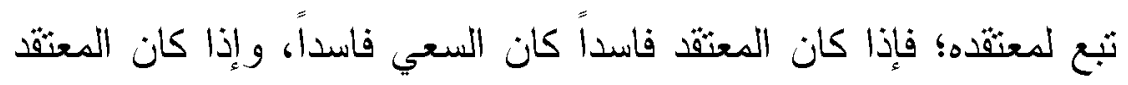
صحيحاً صالحاً صلح سعيه، قال ابن عباس رضي اله عنهما المراد

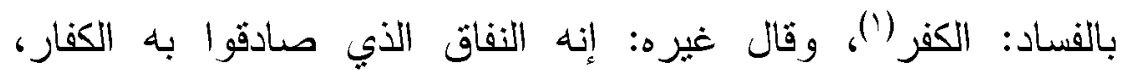
واطلّعوهم على أسرار المؤمنين(r). وعن عمرو بن شرحبيل، عن عبد الله، قال: سألث رسول اله صلى الله علبه وسلم أي الذنب أعظم عند الش؟ قال: 》أن تجعل له ندا

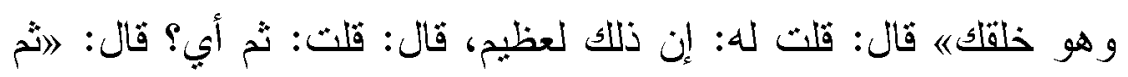

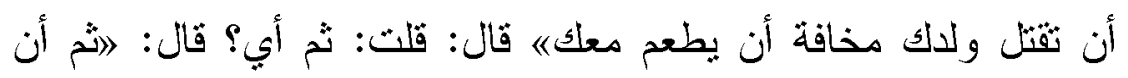
تز اني حليلة جاركي (ب) وكل من الكفر والنفاق اعثقاد فاسد، يفسد به سلوك المره فيسعى في الأرض فساداً ، وكيف يصلح من سلب الإيمان من قلبه ؟ فالكفر

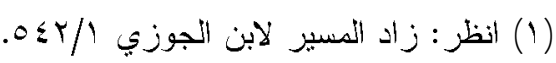

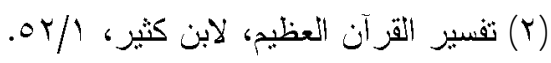

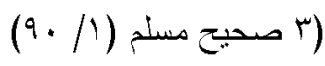


و النفاق نوع من أنواع الفساد بل أقبح الأنواع؛ لأنه المؤثر على مسلك الإنسان وسلوكه.

\section{الفساد الأمني والاجتماعي :}

الأمن أساس النعم، ومن فقد الأمن لا يشعر بسائر النعم ... يقول

الرسول ؛

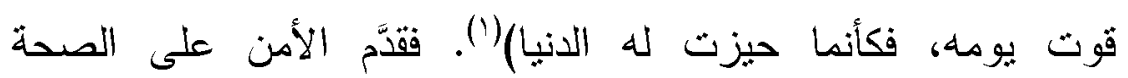
و الرزق

وأن هناك حاجات رئبسية وحقوقاً أساسبة بحتاجها المجتمع، وبدون تحققها لا بمكن أن يستمر نحو تحقيث أهدافه ، وهي حاجاث طبيعية تفرضها ظروف الإنسان الطبيعية من غذاء ، وسكن وسلامة وطمأنينة،

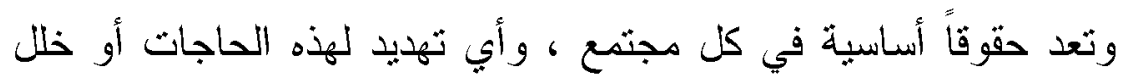

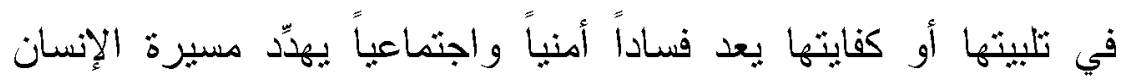
لأداء رسالته.

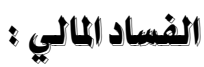

المال هو عصب الحياة ، وقد عني الإسلام بتنظيم علاقات البشر

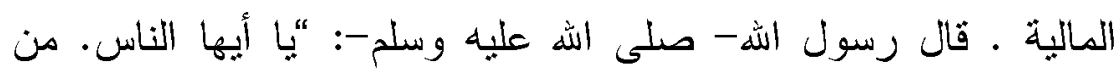

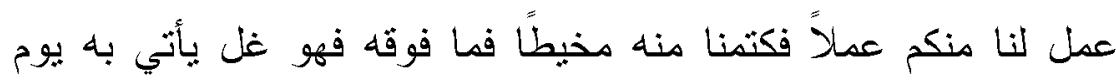
القبامثة، قال: فقام رجل من الأنصار أسود- قال مجاهد: هو سعد بن

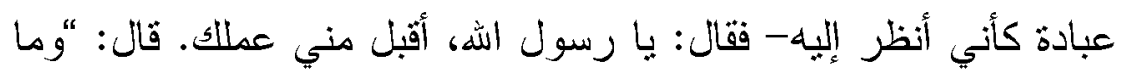
ذاك؟” قال: سمعتك ثقول: كذا وكذا. ثال: “وأنا أقول ذلك الآن. من استعملناه على عمل فليجئ بقليله وكثيره. فما أوتي منه أخذه وما نهي 
عنه انتهى" (رواه مسلم وأبو داود من طرق عن إسماعيل بن أبي رافع) (')

وأن المعاملات الاقتصادية من بيع وشراء وإجارة ومضاربة وما

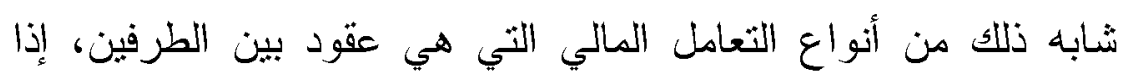

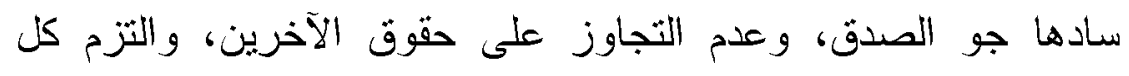

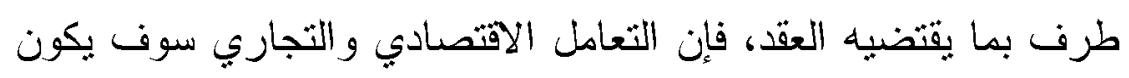

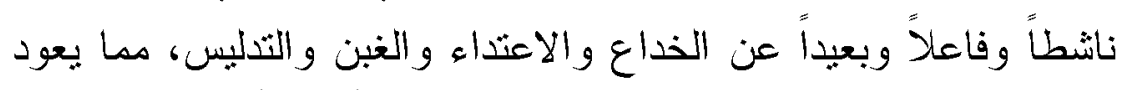

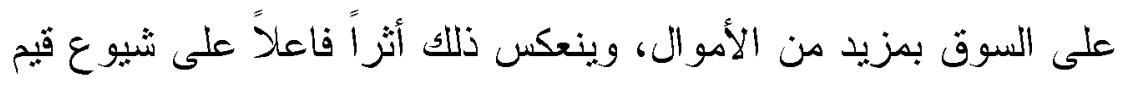

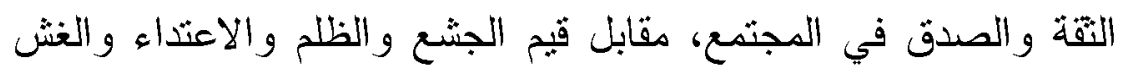

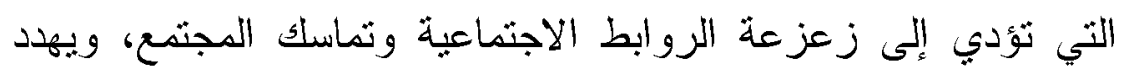

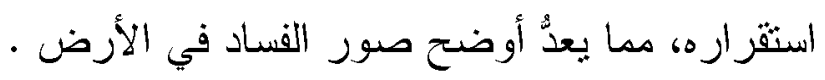

الوفساد الأخلاقي :

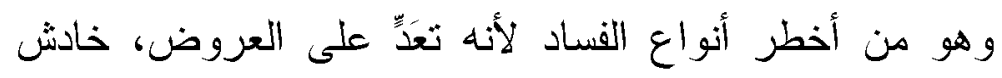

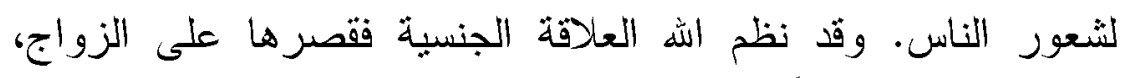
وجعل غير ذللك تعدياً.

فعن عبادة بن الصامت، قال: كان نبي الله صلى الله علبه وسلح

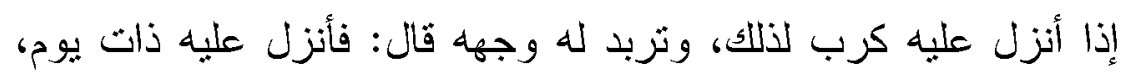
فلقي كذلك، فلما سري عنه، قال: (خذوا عني، فقد جعل اله لهن سبيلا،

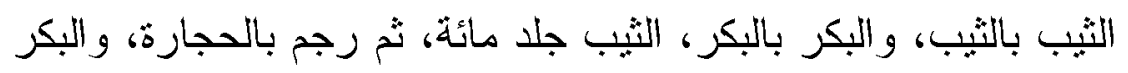

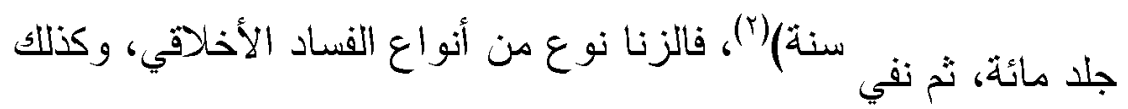
عمل قوم لوط من صور الفساد في الأرض، وهذا العمل الثنائن يؤدي

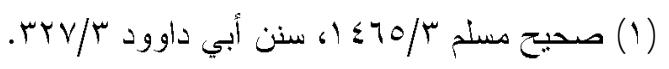

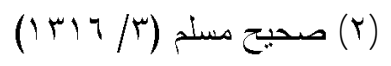


بالإضـافة إلى الأمراض المختلفة إلى تهديد النسل، واسثمرار الوجود البشّري، الأمر الذي لا بحتاج إلى مزيد بيان. والموضوع بطرح في حضارة اليوم تحت عنوان: (المشكلة

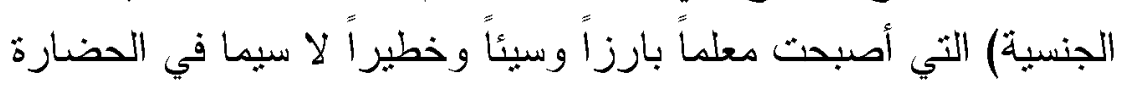
الغربية التي نزيد أن تحكم العالم اليوم، والجنسية المثلية التي يريد الغرب أن يقنها كظاهرة إنسانبة مقبولة، بعثبر ها القرآن من صور آنها ونماذج الفساد في الأرض.

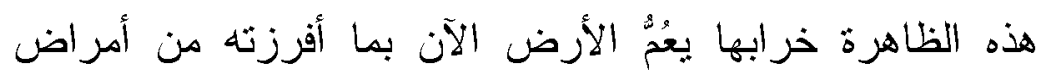
عجيبة مثل الأيدز (طاعون العصر) ولعل هذه المثكلة وتعقدها تعثبر

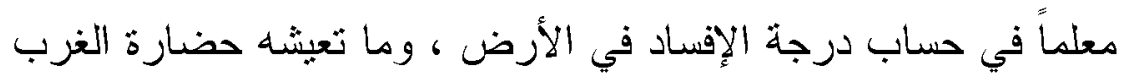
التي تلقى بظلالها السيئة على كل العالم، وهي نموذج جلي لانهيار

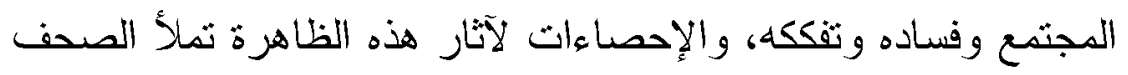
وتفيض بها المجلات. الفساد البيئي : إن قضايا البيئة واجهت البثر في أخريات القرن الماضي

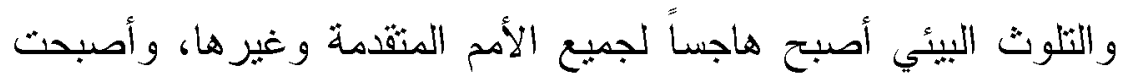

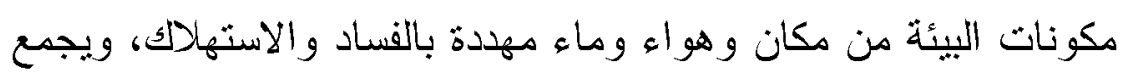

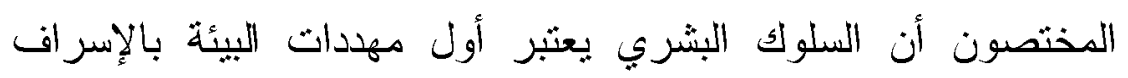
و التبذير و التلوث. ولعلنا نجد الإشارة لهذا في قوله فئل عن أبي هريرة، عن النبي

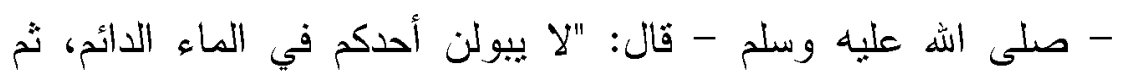
يغتسل منه" (') (1)

$$
\text { (1) سنن أبي داود ت الأرنؤوط (1/ (0) }
$$


وقد أولى الشرع الحنيف أمور البيئة كل العناية، فمن مبادئ

الثنرع عدم الإسراف في استهلاك كل شيء، فثثلاً نهى عن الإسراف في الماء، ولو كان ذلك في الطهارة، ولو كان المتوضي على ضفة نهر جار، وحمى الماء من التلوث، فنهى عن البول في الماء، وعن التبول في أماكن الناس ومواردهم، وإن الاعتداء على الييئة نوع من أنواع الفساد . 


\section{ألمجثثالثالث \\ أسبـاب الفسيــاد}

للفساد أسباب عدة منها ما هو متعلق بالثخص ومنها ما هو طارئ عليه بالمخالطة و غير ها 1 - فأعظم سبب للفساد هو إخلال الناس بشر ع اله وعلى وعلى قدر بعدهم

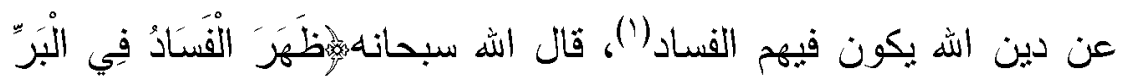

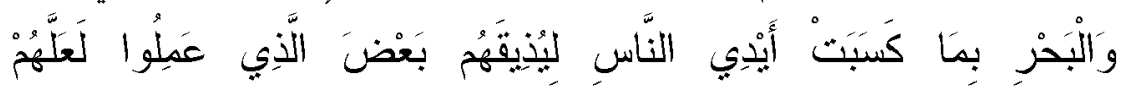

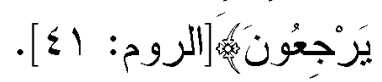

وفُسر الفساد في الآية بالثرك والمعاصي وقطع السبيل و الظام

و القتل و القحط وكساد الأسعار وقلة المعاش (r).

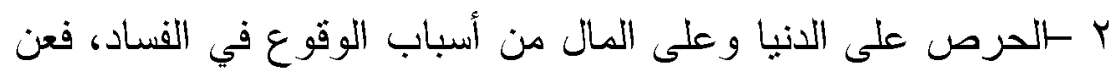
كعب بن مالك الأنصاري، عن أبيه، ثال: ثال رسول اله صلى اله عليه

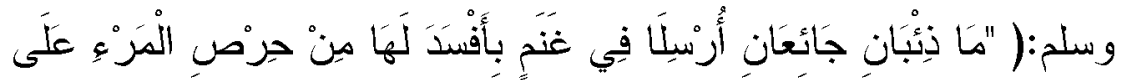

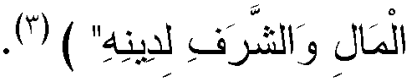
فأخبر النبي صلى الله عليه وسلم أن حرصَ المرءء على الدنبا و الثرف و إقساده لدينه ليس بأقل من إفساد الذئبين لهذة الغنم ،بل إما أن

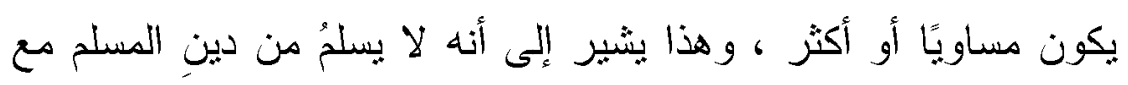

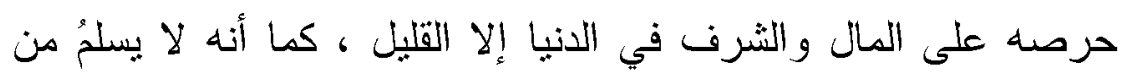

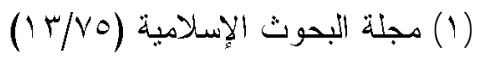

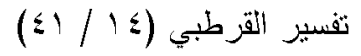

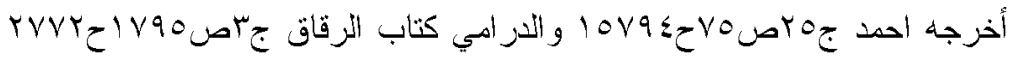

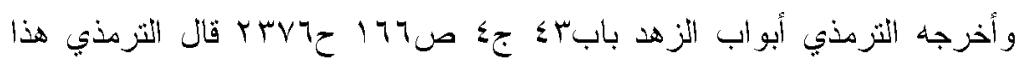

$$
\begin{aligned}
& \text { حديث حسن صحيح. وصححه الألباني }
\end{aligned}
$$


الغنم مع إفساد الذئيين إلا القليل. (').

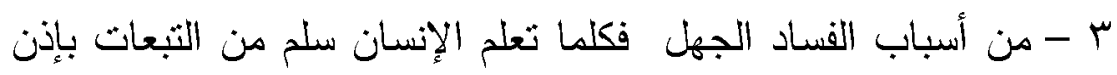

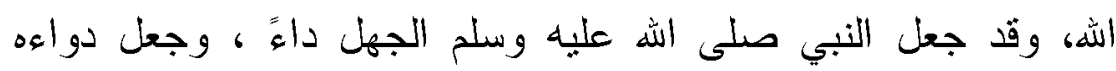

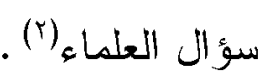
وذكر مفتي المملكة آل الثيخ في مفال له عن الثباب الذين إنحرفوا وراء الأفكار الهدامة قال هي عين الفساد والضدلال ، فنفذوا مخططاتهم عن جهل منهم ، وسوء بصيرة ، وقلة إدر اكل(").

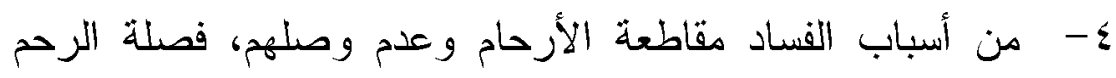
عمران وقطع الرحم فساد، وقد ذكر الله ذلك في القرآن في ثنالاث

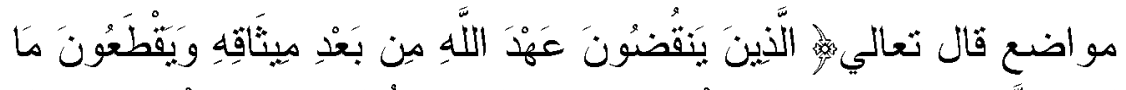

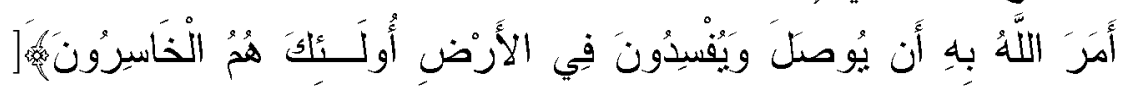

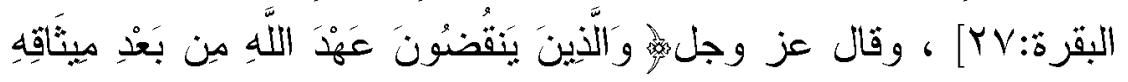

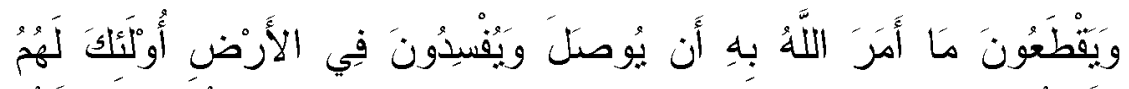

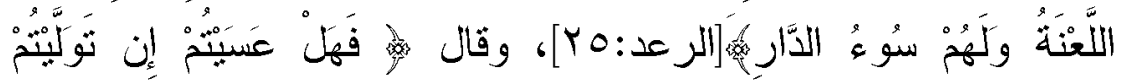

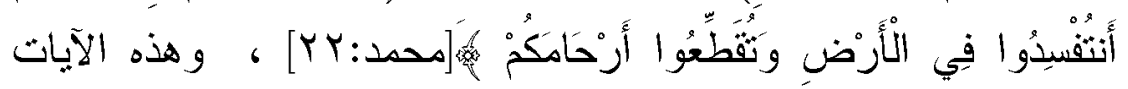

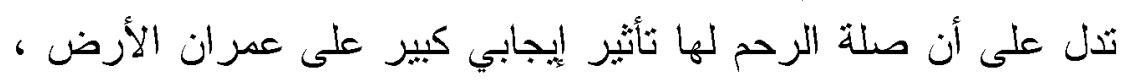
كما أن القطيعة إعلان بالفساد. ه كومن أسباب الفساد ما ثبثه وسائل الإعلام العامة من شرور وسموم وما تحارب به الأخلاق وثوابت الأمه ، وما تتشرة من رذائل قولية

وفعلية ومان

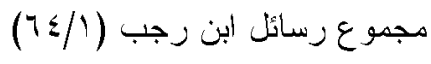

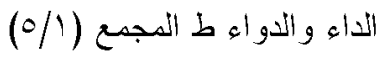

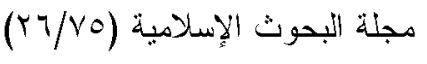

$$
\begin{aligned}
& \text { المرجع السابق (r./Vo) }
\end{aligned}
$$




\section{الإبحث الرابع \\ آثـار الفسيــاد}

للفساد آثار وخيمة على الفرد و على المجتمع منها:

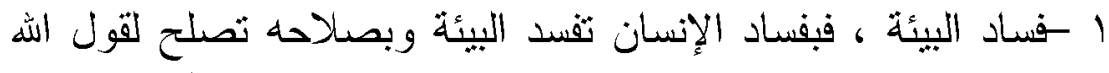

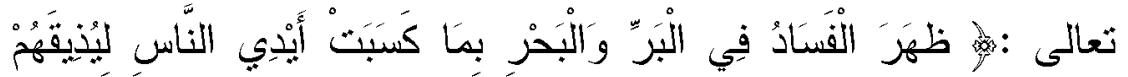

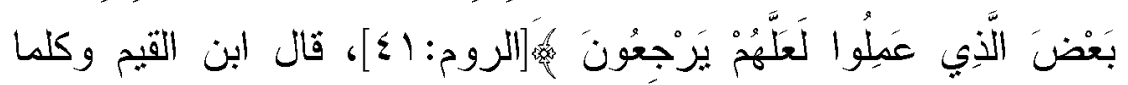
أحدث الناس ظلمآ وفجورآ ، أحدث لهح ربهم نبارلك وتعالي هن الآفات و العلل في أغذيتهم وفو اكههم ، واهويثهم ومياههم ، وأبدانهم وخلقهم ،

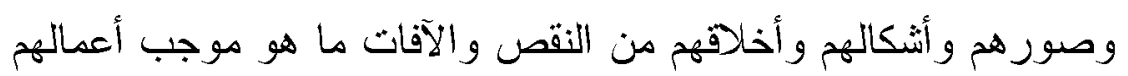

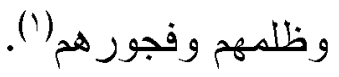
r - من آثار الفساد الوقوع في مفسدة أعظم قال ابن ثيمبة منحدثا عن الخروج على الولاة: ولعله لا بكاد يعرف طائفة خرجت على ذي سلطان إلا وكان خروجها من الفساد ما هو أعظم من الفساد الذي أزالته(ז)، وقال في المجموع: فلا يجوز دفع الفساد القليل بالفساد الكثير

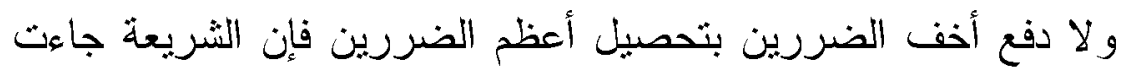
بتحصبل المصالح وتكمبلها، وتعطيل المفاسد وتثليلها بحسب الإمكان("). r -إن الفساد بعدب صاحبه فالصاحب ساحب يسحبك للخير أو للشر قال سفيان : ليس شئ أبلغ في فساد رجل وصدلاحه من صاحب(؛)؛ وقال ممشاد الدينوري المثوفي سنة تشع ونسعين ومائتين رحمة الله

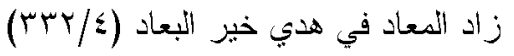

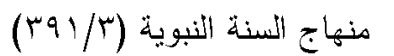

$$
\begin{aligned}
& \text { مجمو ع الفتاوى (S }
\end{aligned}
$$

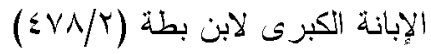


تعالي : صحبة اهل الصلاح ثورث في القلب الصلاح ، وصحبة أهل

الفساد تورث فيه الفساد (1).

ـ - إن الفساد في الأرض بالتمرد و العصيان والجور في الحكم ، سبب

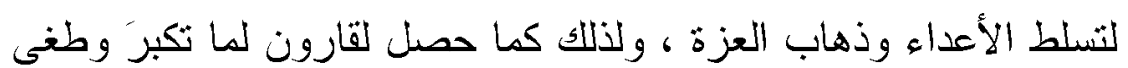

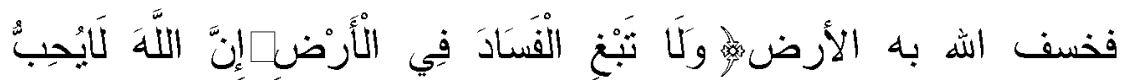

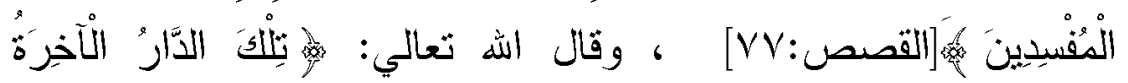

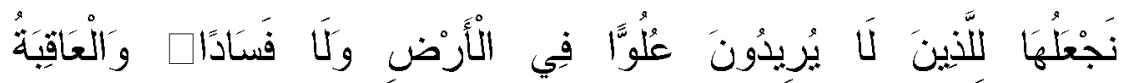

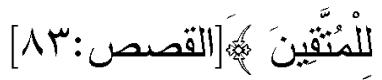
ه - إنتشار الأمراض فالمُفسد فاقد للأمن النفسي والاسثقرار العقلي حيث بســيطر القلق والاضطر اب عليه. 


\section{المبحث الخامس \\ تصدي الثرع للفساد}

سلك الشر ع الحنيف في الثصدي للفساد مسلكين:

الأول: توجيهي وإرشادي وتحذيري.

وقد ثمثل مسلك التوجيه والإرشاد و التحذير في الآتي :

- الأمر بالمعروف والنهي عن المنكر :

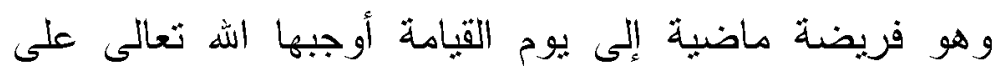

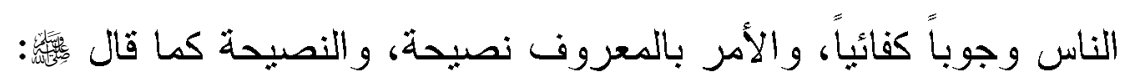

(لله ولرسوله و لأئمة المسلمين و عامتهم) (').

ويقول : نس

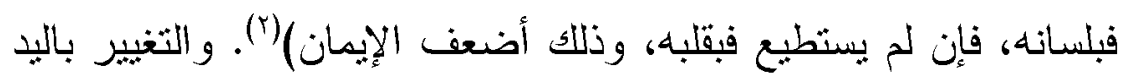

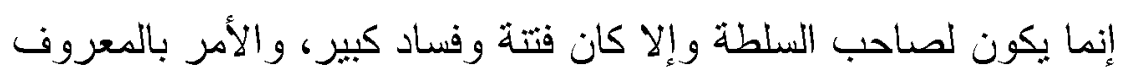
و النهي عن المنكر أنجع السبل للحد من الفساد وأسبابه. ينبغي في المصلحين الإخلاص، وإلا فإن كلامهم يفقد أثره، بل يكون ثأثيره في الناس عكسباً لأن منطق الناس يصبح أنه لو كان ما الأ فان يقال صحيحاً لعمل قائله به فالتناقض بين دعوة المصلح وبين مسلكه

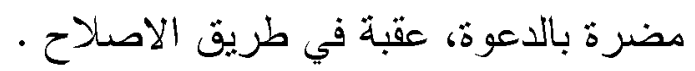

والتزام الداعية بما بدعو إلبه تجعله قدوة للناس بفعله، ولعل

دلالة الفعل في بعض الأحيان نكون أقوى من دلالة القول. - الدعوة إلى الإصـلاح بالحكمة.

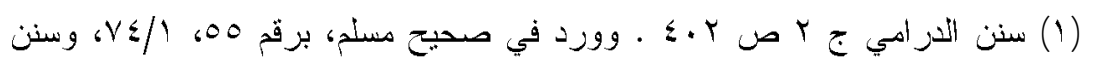

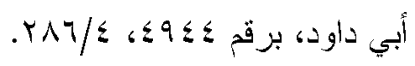

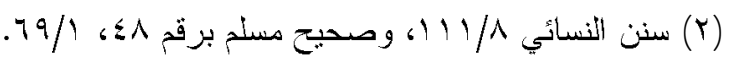


- - عدم اتباع سبيل المفسدين.

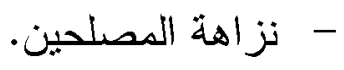

الثثاني: عقابي نمثل في عقوبات من السلطة ضد المفسدين. من سماحة الثريعة الإسلامية أنها كفلت للناس حفظ فئ فئ الكلبات

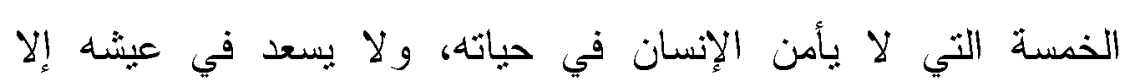

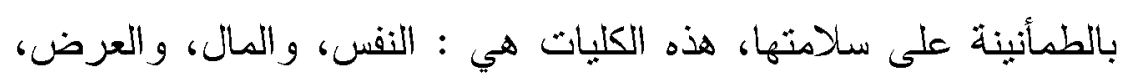

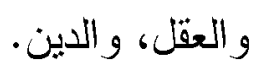

وجعلت كل ثهديد وتعَدِ على هذه القيم، ضرباً من ضروب

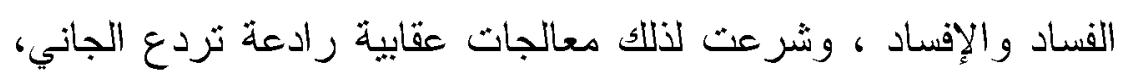
وتزجر غيره عن التعدي عليها، معروفة بالعقوبات الحدية، فالمعتدي على النفس البشرية شرع الله القصاص، والمعتدي على المال بالسرقة

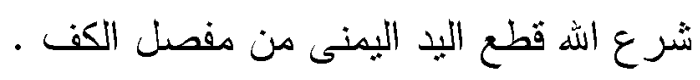
والتعدي على الأعر اض بالزنا جعل الله عقوبثه جلد البكر ورجم المحصن و المحصن هو الذي جامع في نكاح صحيح، وفي ذلك يقول النبي و الثيب بالثيب جلد مائة و الرجم)(').

أما التعدي بالفساد على العقل وذللك بشرب المسكر، فقد جلد فيه

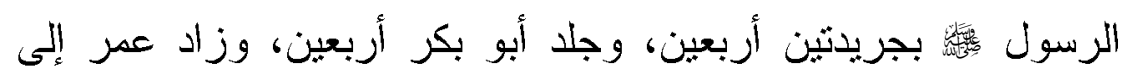
ثمانين وكله سُنَّة (r). 


\section{الفساد دراسة موضوعية في السنة النبوية}

والتعدي على الدين بتمثل في الردة بعد الإيمان، وفي

هذا يقول بـ

وهذا الجانب العقابي في التصدي للفساد منوط بولي الأمر

صاحب السلطة لا يباشره غيره، فنكون فيتة في الأرض وفساد كيير. 


\section{مجلة كلية اللدراسات الإسلامية والعربية بنات-دمنهور العدد الأول -المجلد الثالث 17rمام}

\section{مقـوبــة الــفسبـاد السادس}

المفسد مهما طال ليله لابد أن ينكثنف أمره، ويرى نتاج مفسدته

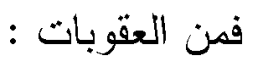

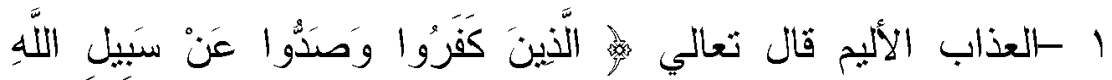

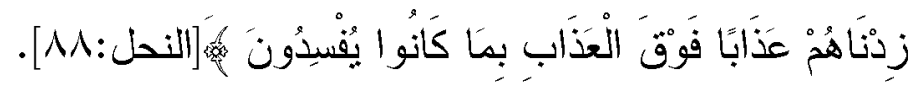

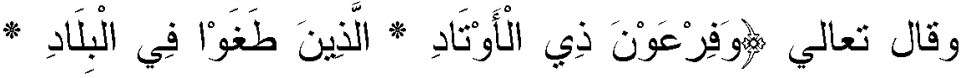

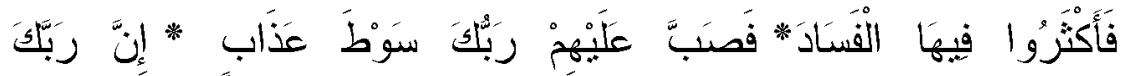

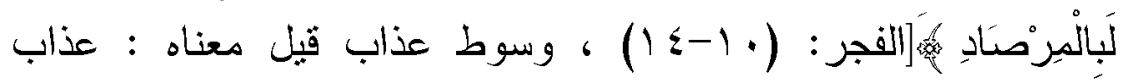

يخالط اللحم والام ، ومن قولهم : يسوطه سوطآ ، أي : خلطه (1).

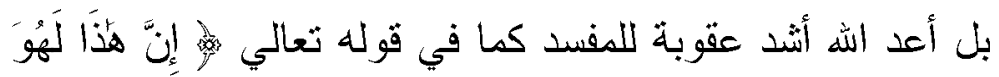

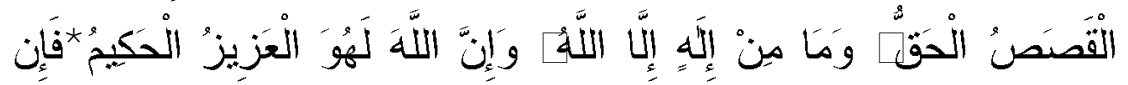

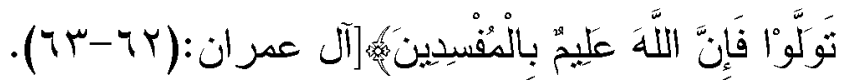

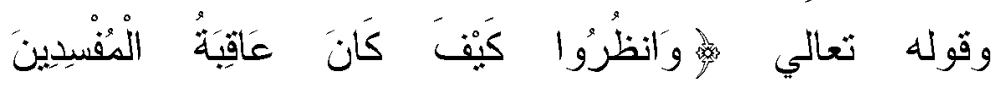

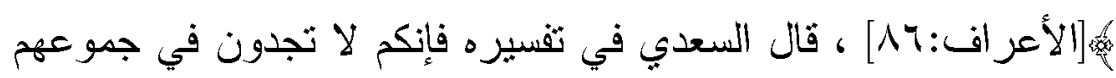
إلا الثتات ، و لا في ربوعهم إلا الوحشة و الانبتات ولم يورثوا ذكرى حسناً ، بل أتبعوا في هذه الدنبا لعثة ، ويوم القيامة أثند خزيى وفضبحة

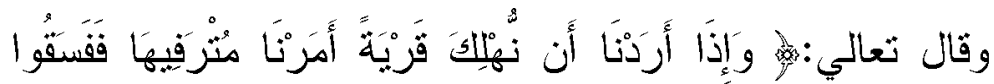

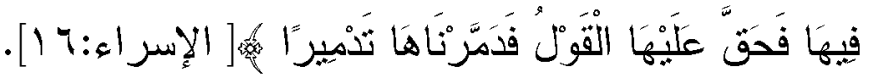

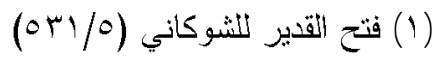

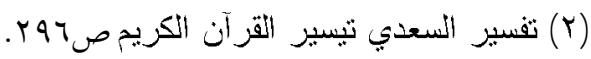


Y -العقوبة في النفس من هم وغم وغير ها، قال ابن الجوزي في كتابه : كان إبراهيم الخواص جالسا في مسجد الري وعنده جماعة إذ سمع ملاهي من الجيران، فاضطرب من ذلك من كان في المسجد وقالوا: با أبا إسحاق ما ثرى؟ فخرج إبراهيم هن المسجد نحو الدار التي فيها المنكر فلما بلغ طرف الزقاق إذا كلب رابض فلما قرب منه إبراهيم نبح عليه وقام في وجهه. فرجع إبراهيم إلى المسجد وتفكر ساعة ثم قام

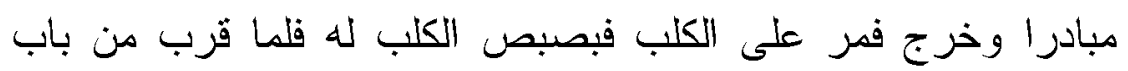
الدار خرج إلبه شاب حسن الوجه وقال: أيها الثيخ لم انزعجث؟ كنت

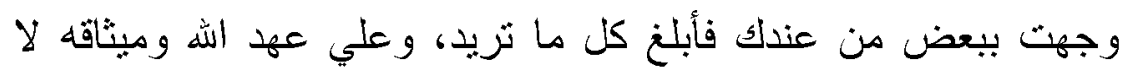
شربت أبدا وكسر الجميع ما كان عنده من الثراب و آلته وصحب أهل الخير ولزم العبادة.ورجع إبراهيم إلى مسجده فلما جلس سئل عن خروجه في أول مرة ورجوعه، ثم خروجه في الثانية وما كان من أمر إنر الكلب، فقال: نعم، إنما نبح علي الكلب لفساد كان قد دخل علي في عقد بيني وبين الله لم أنتبه له في الوقت، فلما رجعت إلى الموضع ذكرثه فاستخفرث الهه عز وجل منه. ثم خرجث الثانية فكان ما رأيتم، وهكذا كل من خرج لإزالة منكر فتحرك عليه شيء من المخلوقات فلفساد عقد بينه وبين الله عز وجل، فإذا وقع الأمر على الصحة لم بتحرك عليه شي (1) ب كومن عاقبة المفسدين أن الهه يبطل اعمالهم ويخيب آمالهم قال ثعالي:

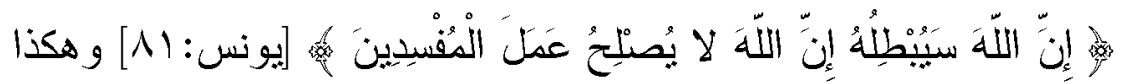
كل مفسد عمل عملا واحتال كيدى ، أو أثى بمكر ، فإن عمله سبيطل 
ويضمحل ، وإن حصل لعمله روجان في وقت ما ، فان مآله

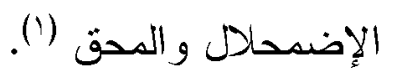

مع هذا كله فالله سبحانه وتعالي أحكم الحاكمين و لا بظلم ربك أحدآ فلا بستوي الناس في العقوبنقال ابن ثيمية رحمة اللهوكلما اثتثا

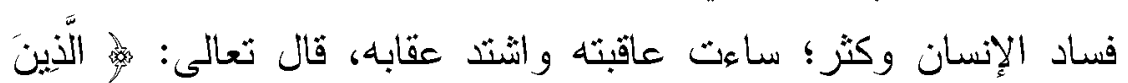

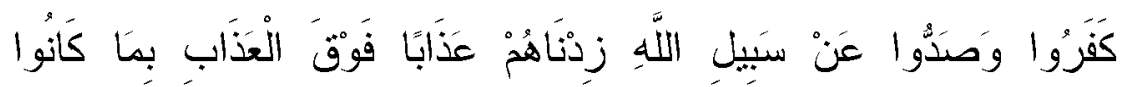

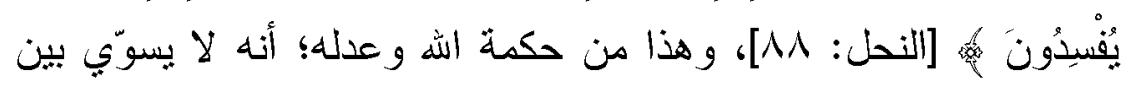

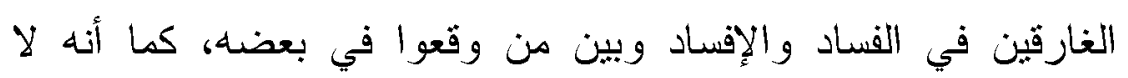

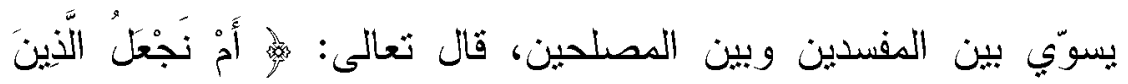

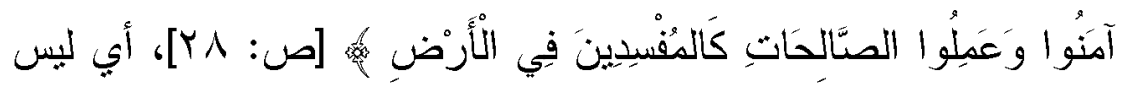

ذلك بلائق بحكمة الألو هية وعدل الربوبية (r).

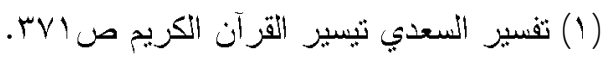

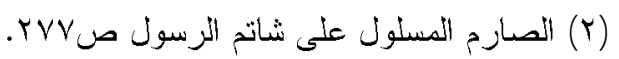




\section{المبحث السادس \\ ملاج الفساد}

لكل داء دواء فالقساد داء ينخر في المجثمعاث ولكن لابد

للإنسان أن يجعل حداً لهذا الداء حتي لاينتشر ويسنشري في المجنمع داءع فمن العلاج : (1)

الأمر بالمعروف والنهي عن المنكر والأخذ على أيدي المفسدين،

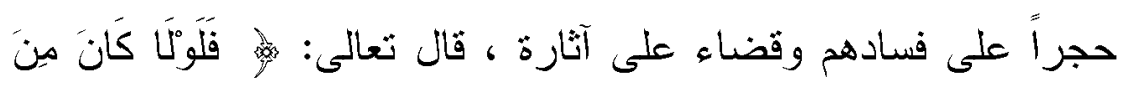

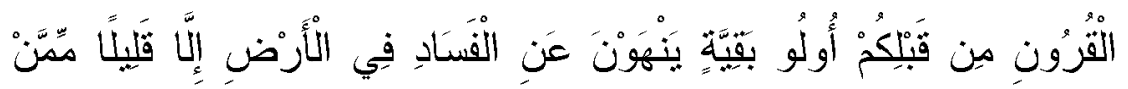

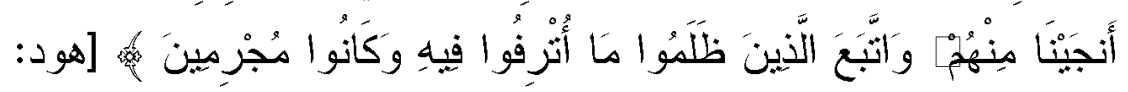

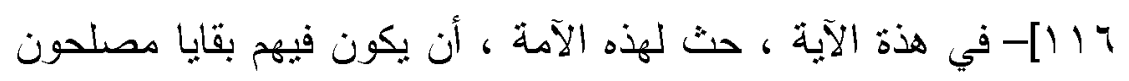

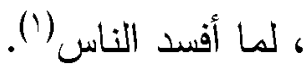
r كمن علاج الفساد: التازرر والتعاون والتتاصر والثضامن بين المسلمين وتحقيق الإيمان والأخوة الإسلامية (r)، قال شيخ الإسلام ابن ثيمية : وباب الفساد الذي وقع في هذه الأمة بل وفي غير ها : هو الإنمان التفرق والاختلاث ؛ فإنه وقع بين أمرائها وعلمائها من ملوكها و مثايخها وغيرهم دن ذلك ما الله به عليم (r)، فلابد من التعاون بين المسلمبن. ب - الحدود الثرعبة علاج ناجح للقضاء على الفساد والتي بحاول أعداء الله إلخاء هذه الحدود ويثباكون على حقوق الإنسان وهم أول من

$$
\begin{aligned}
& \text { (1) تفسير النسعبي تيسير القزآن الكريم ص اوه. } \\
& \text { (Y) تفسير البغوي إحياء النزراث (r/r/r) }
\end{aligned}
$$

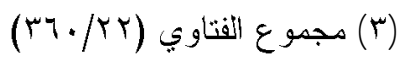




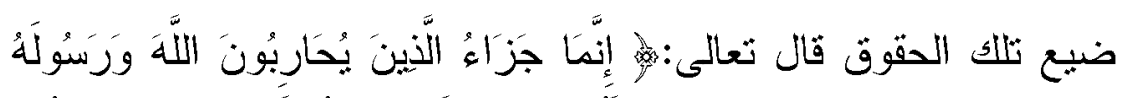

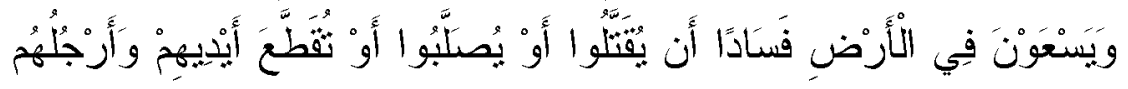

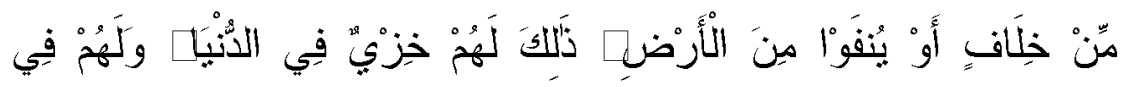

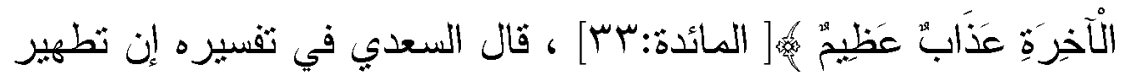

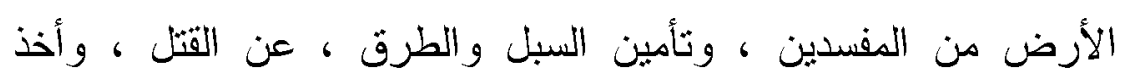

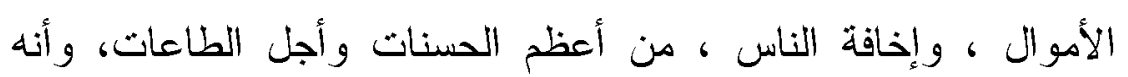

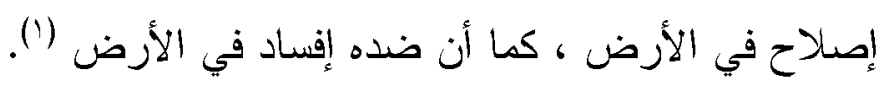

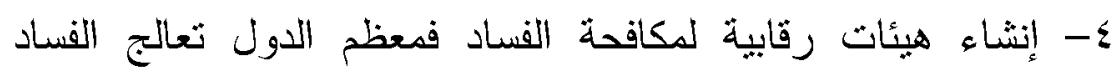
وتحاول ردع أهله وفي المملكة العربية السعودية نم إنثاء الهيئة

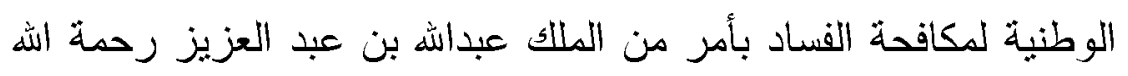

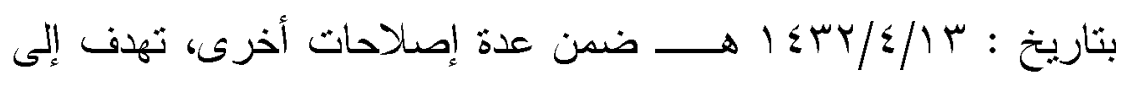

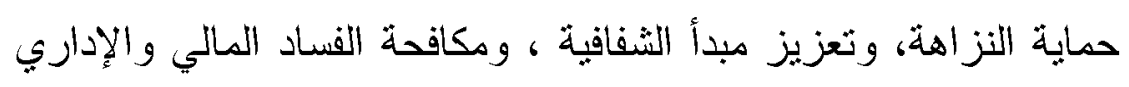
بثتى صوره ومظاهره وأساليبه . 0- الرقابة الذانية و الصلاح. 


\section{الخاتمة}

وبعد أنْ هَنَ علي الله بالفراغ هن هذا البحث أذكر النتائج الآتية:

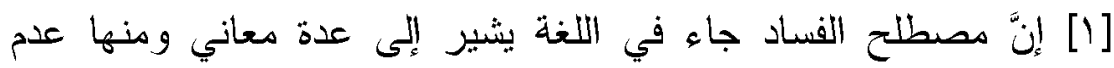

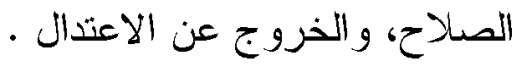

[ץ] الفساد أمر تبغضه الطبيعة البشرية المعتلة وتتوق إلى نقيضه وهو الاعدو - الصالخ

[r] جاء الفساد و النهي عنه في أغلب النصوص في السنة مرتبطاً بذكر الأرض التي هي دسرح حياة الإنسان، وتتفّر هنه وتطالبنا بالإنتهاء عنه فئه فئه

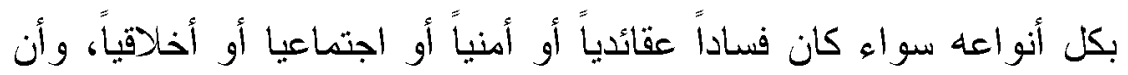
المفسد ههيا طال ليله لابد أن ينكثف أمره، ويرى نتاج هفسدته، فالله سبحانه وتعالى يمهل و لا يههل. [؛] لقد تصدى الثرع الحنيف للفساد بما يحول دون وقو عه ومعالجته إذا

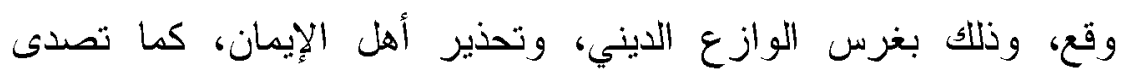

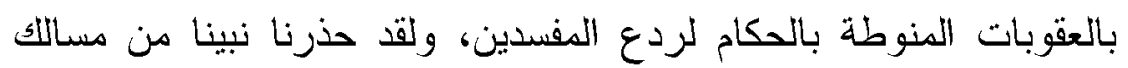

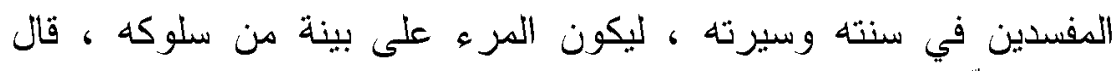

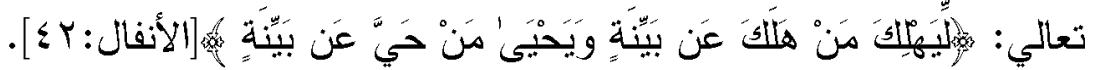
[0] إنَّ أكبر هفاسد العصر تتمنل في الاعتداء على العقول بالمسكرات

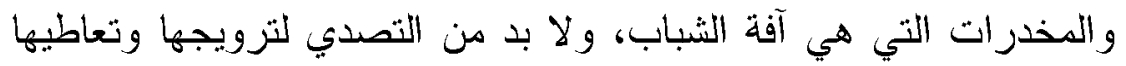

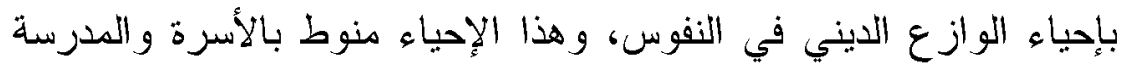
و المسجد والإعلام، وكذلك التصدي لها من جهة أجهزة الأمن التي ينبغي أن يوفر لها السبل من الكفاءة والدراية والخبرة . [7] إنَّ جرائم غسيل الأموال وتزوير الأوراق النقدية والاعتداء على أموال الغير بوساطة الإنترنت يعتبر هن الفساد المالي الذي يهدد اقتصاديات

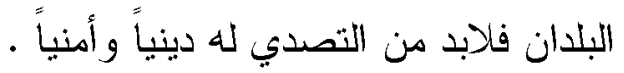




$$
\text { فهرس المصادر والمراجع }
$$

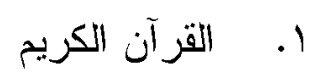

Y. الإبانة الكبرى لابن بطة أبو عبد الله عبيد الله بن محدد بن محمد بن

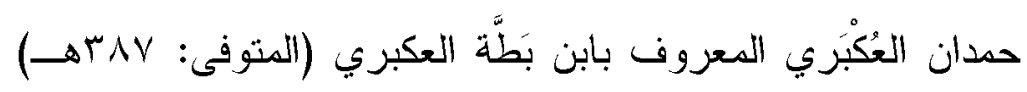

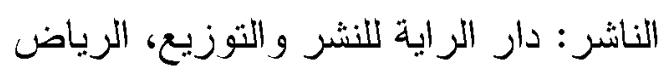

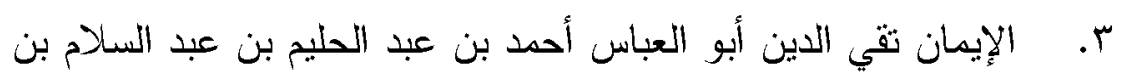

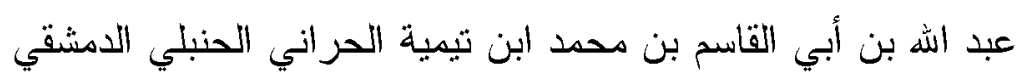

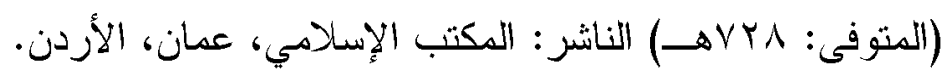

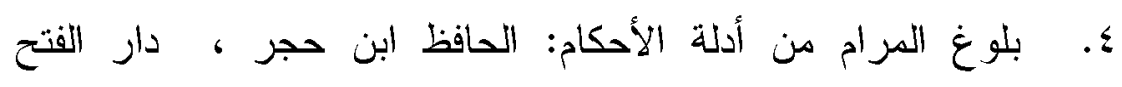

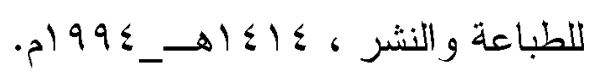

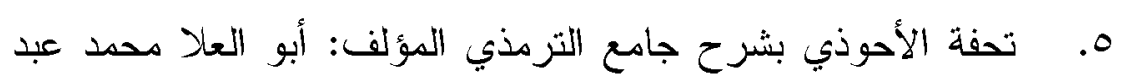

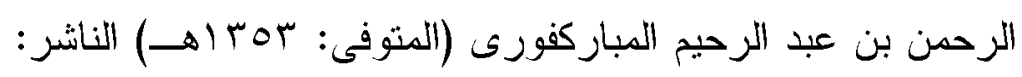
دار الكتب العلمية - بيروت المغني ابني قدامة : موفق الدين

$$
\text { وشس الدين ابني قدامة }
$$

7. تحفة الحبيب على شرح الخطيب : علي الخطيب ، بيروت ، دار

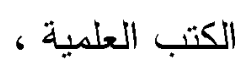

V. تحفة الذاكرين بعدة الحصن الحصين دن كلام سيد المرسلين

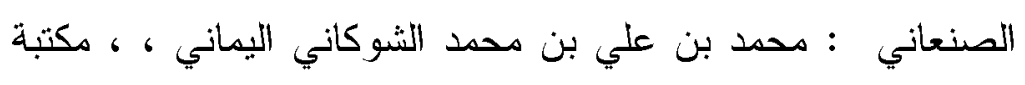

$$
\text { المتببي ك. القاهرة }
$$

^. التعريفات الجرجاني : علي ، ، بيروت ، دار الكتب العلدية . 9.

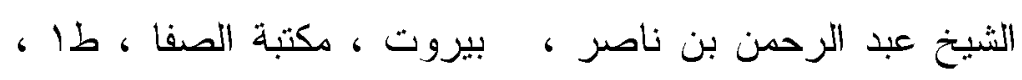

$$
\text { • }
$$


• ا. تيسير الكريم الرحمن في تفسير كلام المنان عبد الرحمن بن ناصر بن عبد الله السعدي (المتوفى: بV آهــ الناشر : مؤسسة الرسالة

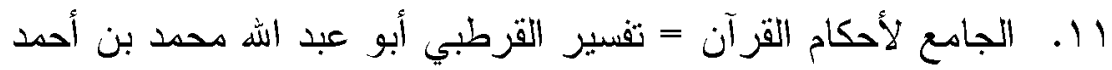
بن أبي بكر بن فرح الأنصاري الخزرجي شمس الدين القرطبي (المتوفى: الحTهـ) الناشر: دار الكتب المصرية - القاهرة

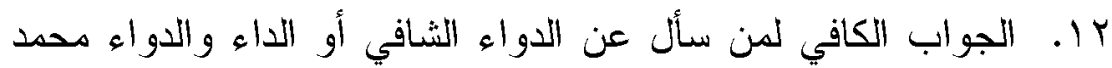
بن أبي بكر بن أيوب بن سعد شمس الدين ابن قيم الجوزية

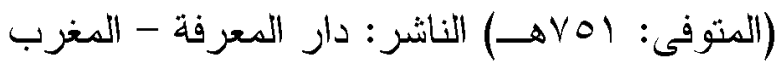

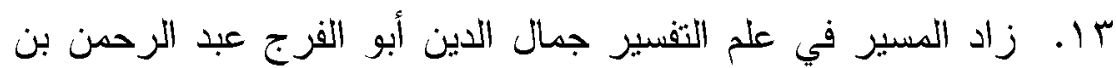
علي بن محمد الجوزي (المتوفى: V09هـ) الناشر: دار الكتاب

$$
\text { العربي - بيروت }
$$

ع ا. زاد الدعاد في هدي خير العباد : الحافظ أبي عبد الله محد بن أبي

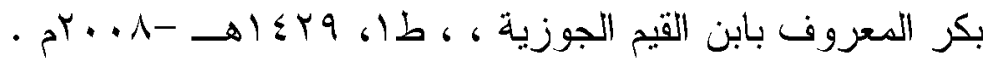

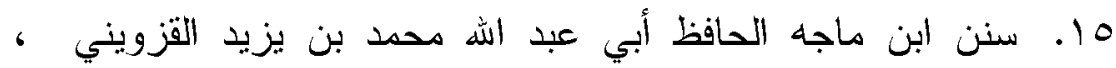

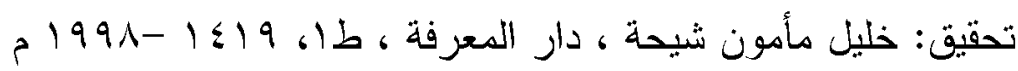

17. سنن الترمذي: أبو عيسى هحمد بن عيسى بن سوره ، القاهرة ، دار

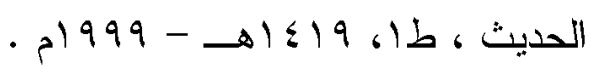

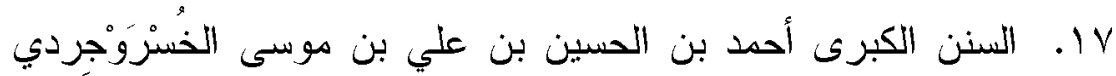

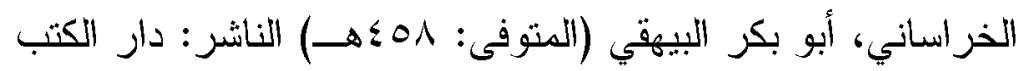
العلمية، بيروت - لبنات 11. شرح كتاب الرقاق دن صحيح البخاري أبو هاشم صالح بن عوّاد بن صالح المغامسي مصدر الكتاب: دروس صوتية قام بتفريغها موقع الشبكة الإسلامية 
9 1. شعيب الأرنؤوط - عادل مرشد، وآخرون إثراف: د عبد الله بن

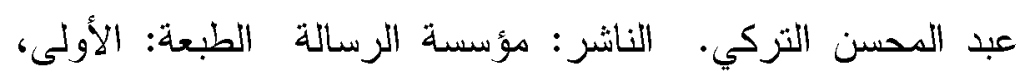

$$
\text { م. Y I } \rightarrow 1 \leq Y 1
$$

•r. الصارم المسلول على شاتم الرسول تقي الدين أبو العباس أحدد بن عبد الحليم بن عبد السلام بن عبد الله بن أبي القاسم بن محمد ابن

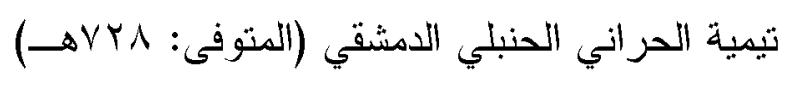

الناشر: الحرس الوطني السعودي، المملكة العربية السعودية

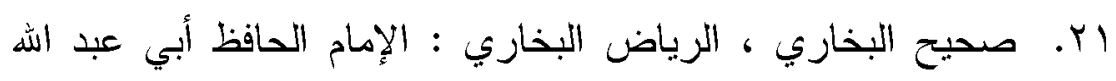

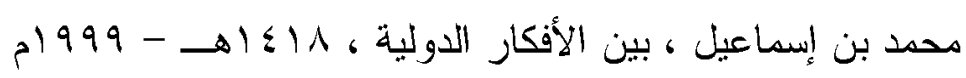
Y Y. صحيح دسلم : الإمام أبو الحسين sسلم بن الحجاج القتيري النيسابوري ، تحقيق : فؤاد عبد الباقي ، دار إحياء الكتب العربية

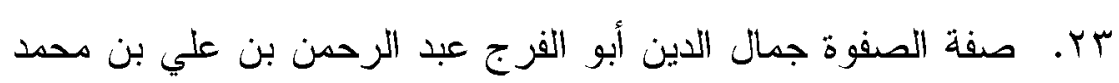

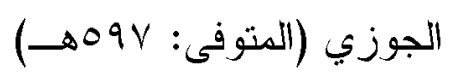

گ ب. فتح الباري بثرح صحيح البخاري ابن حجر: أحمد بن علي بن

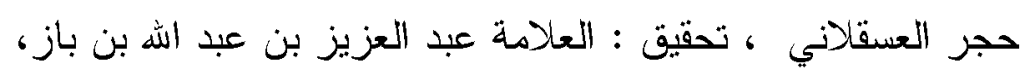

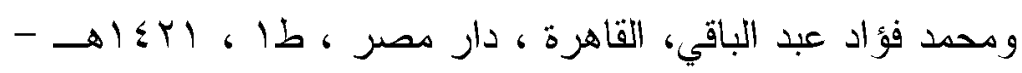

$$
\cdot{ }^{2}+\cdots
$$

هr. فتح القدير محدد بن علي بن محد بن عبد الله الثوكاني اليمني

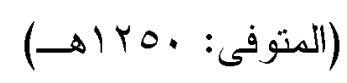

الناشر: دار ابن كثير، دار الكلم الطيب - دمشق، بيروت

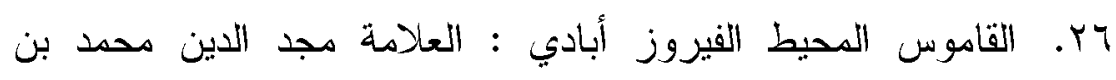

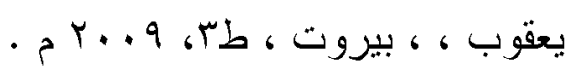

rV الله بن محمد بن إبراهيم بن عثمان بن خواستي العبسي (المتوفى: 


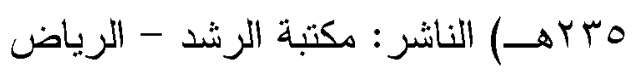

^. . كنز العمال في سنن الأقوال والأفعال علاء الدين علي بن حسام الدين ابن قاضي خان القادري الشاذلي الهندي البرهانفوري ثن المدني فالمكي الثهير بالمتقي الهندي (المتوفى: 9v0هـ) الناشر : مؤسسة الرسالة

9r. لسان العرب ابن منظور : جمال الدين محمد بن المكرم ، ، بيروت

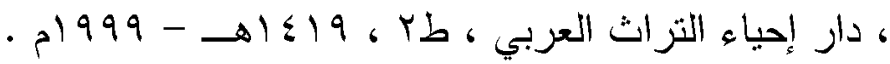
•r. دجلة البحوث الإسلامية - دجلة دورية تصدر عن الرئاسة العامة

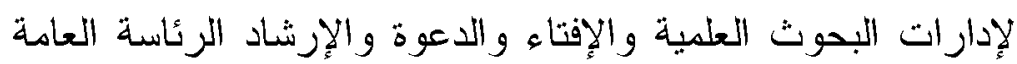
لإدار ات البحوث العلدية و الإفتاء و الدعوة و الإزشاد ابـ هموع الفتاوى ثقي الدين أبو العباس أحدد بن عبد الحليم بن تيمية

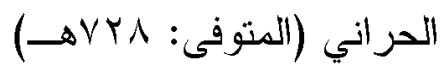

الناشر : مجع الملك فهد لطباعة المصحف الثريف، المدينة النبوية، المملكة العربية السعودية rr. مجموع رسائل الحافظ ابن رجب الحنبلي زين الدين عبد الرحمن

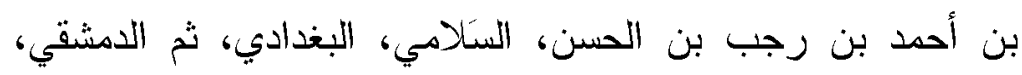
الحنبلي (المتوفى: بولهـ) الناشر: الفاروق الحديثة للطباعة والنثر rr. المحكم والمحيط الأعظم أبو الحسن علي بن إسماعيل بن سيده

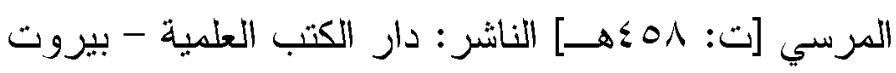
§. أ. المستدرك على الصحيحين أبو عبد الله الحاكم محمد بن عبد الله بن

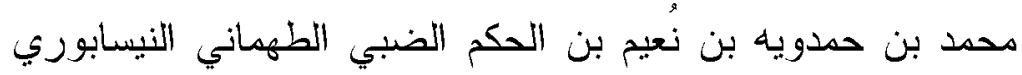
المعروف بابن البيع (المتوفى: 0. كهــ) الناشر: دار الكتب العلية 
هr. مسند الإمام أحمد بن حنبل المؤلف: أبو عبد الله أحمد بن محمد بن

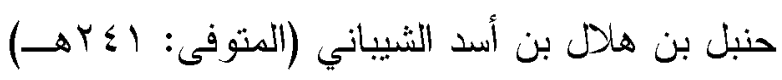

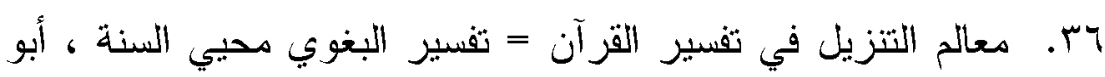
هحد الحسين بن مسعود بن محمد بن الفراء البغوي الثنافعي

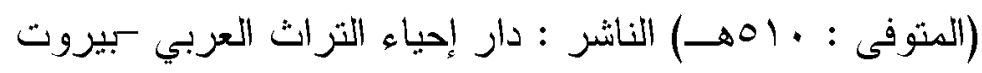

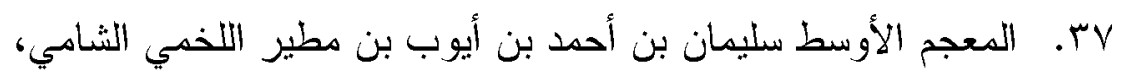

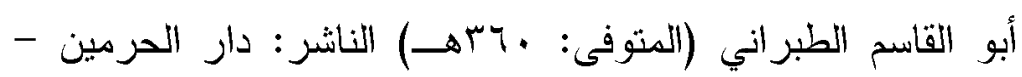
القاهرة

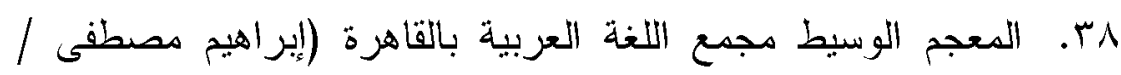

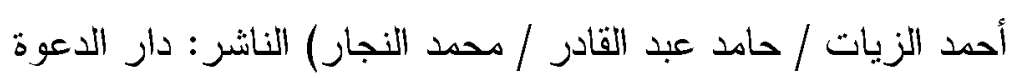

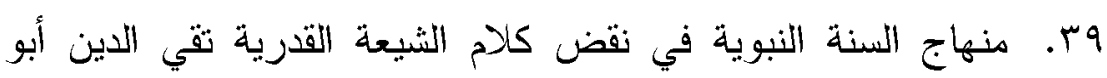
العباس أحمد بن عبد الحليم بن عبد السلام بن عبد الله بن أبي القاسم

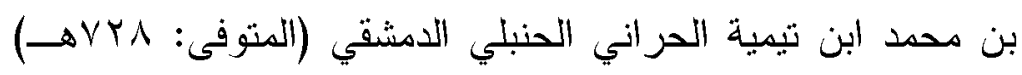

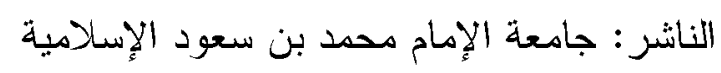

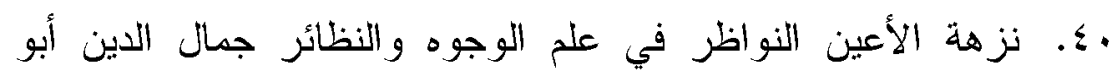

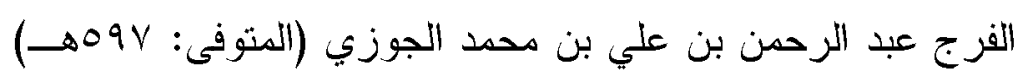

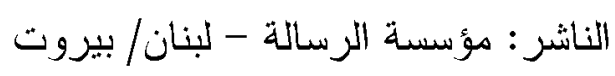

